\title{
Yenidoğanın Geçici Takipnesi ile Hastaneye Yatırılan Yenidoğanların Ebeveynlerinin Kaygı Düzeyi ve Etkileyen Faktörler
}

\author{
Fatmanur Tekin ${ }^{1} \oplus$, Meltem Kürtüncü̈
}

'Zonguldak Bülent Ecevit Üniversitesi Sağlık Bilimleri Fakültesi Hemşirelik Bölümü, Çocuk Sağlığı ve Hastalıkları Hemşireliği Anabilim Dalı, Zonguldak, Türkiye

${ }^{2}$ Zonguldak Kadın Doğum ve Çocuk Hastalıkları Hastanesi, Zonguldak, Türkiye

Fatmanur Tekin, Uzm Hemşire Meltem Kürtüncü, Doç. Dr.

İletişim:

Doç. Dr. Meltem Kürtüncü

Zonguldak Bülent Ecevit Üniversitesi Sağlık Bilimleri Fakültesi Hemşirelik Bölümü, Çocuk Sağlı̆ı ve Hastalıkları Hemşireliği Anabilim Dalı, Zonguldak, Türkiye

Tel: +903722613343

E-Posta: meltem.kt@beun.edu.tr

Gönderilme Tarihi : 27 Şubat 2019 Revizyon Tarihi : 18 ekim 2019 Kabul Tarihi : : 03 Kasım 2019
ÖZET

Amaç: Bu çalışma, yenidoğanın geçici takipnesi (YGT) ile hastaneye yatırılan bebeklerin ebeveynlerindeki kaygı düzeyi ve ilişkili faktörlerin belirlenmesi amacıyla gerçekleştirildi.

Yöntem: Bu çalışma tanımlayıcı ve analitik tiptedir. Şubat- Ağustos 2017 tarihleri arasında bir kamu hastanesinin yenidoğan yoğun bakım ünitesinde gerçekleştirildi. Çalışma örneklemini 200 ebeveyn oluşturdu. Verilerin toplanmasında Spielberg'in “Durumluluk ve Sürekli Kaygı Ölçeği” ile “Ebeveyn Bilgi Formu” ve “Bebek Bilgi Formu” kullanıldı.

Bulgular: Çalışmada, ebeveynlerin durumluk kaygı düzeyleri $(40,17 \pm 10,80)$ hafif, sürekli kaygı düzeylerinin $(52,59 \pm 5,10)$ yüksek olduğu saptandı. Anne ve babaların kaygı düzeyleri karşılaştıııdığında; süreklik kaygı düzeylerinde $(p=0,009 ; p<0,01)$, babaların puanı annelerden daha yüksek olduğu görüldü. Ebeveynlerin bebeklerinin hastalığı hakkında, yeterince bilgilendirilme durumuna bakıldığında; bilgilendirilen ebeveynlerin durumluk kaygı puanı bilgilendirilmeyenlerden anlamlı düzeyde düşük ( $p=0001 ; p<0,01)$ olduğu belirlendi. Ebeveynlerin bebeklerini ziyaret ettikleri sırada hissettikleri duyguya göre; durumluk kaygı puanları incelendiğinde $(p=0,001 ; p<0,01)$; üzüntü yaşayanların $p u-$ anlarının, mutlu olanlardan $(p=0,032)$ ve anksiyete yaşayanlardan $(p=0,001)$ anlamlı düzeyde yüksek olduğu görüldü $(p<0,05)$.

Sonuç: Bu araştırmanın sonuçları yenidoğan hemşiresinin anne babaların kaygılarını azaltmaya yönelik planlama yapmasının önemine işaret etmektedir.

Anahtar sözcükler: Ebeveyn, kaygı, yenidoğan, yenidoğanın geçici takipnesi

NEWBORNS' HOSPITALIZED WITH TRANSIENT TACHYPNEA' OF THE NEWBORN, PARENTS' ANXIETY LEVEL AND AFFECTING FACTORS

\section{ABSTRACT}

Objective: This research aims to determine the anxiety level of the parents of babies hospitalized with a diagnosis of transient tachypnea of newborn and related factors.

Method: This is a descriptive research. The research was done between February-August 2017 in the neonatal intensive care unit of a public hospital. Research sample consists of 200 parents. In order to collect data, Spielberger's "State-Trait Anxiety Inventory" and "Parent Information Form" and "Infant Information Sheet" are used.

Results: The study shows that state anxiety levels of parents $(40.17 \pm 10.80)$ are mild, continuous anxiety levels $(52.59 \pm 5.10)$ are found to be high. Comparing parents' anxiety levels; the trait anxiety level $(p=0.009 ; p<0.01)$ score of fathers is seen to be higher than the mothers. Considering the anxiety levels of sufficiently informed parents about the disease of their babies, state anxiety of informed parents score is significantly lower than those who are not informed $(p=0001 ; p<0.01)$. According to the emotions of parents during the visit of their babies; state anxiety scores $(p=0.001 ; p<0.01)$; the score of those who feel sad $(p<0.05)$ is significantly higher than those who feel happy $(p=0.032)$ and anxious $(p=0.001)$.

Conclusion: Results show that the anxiety level of the parents of babies hospitalized with a diagnosis of transient tachypnea of newborn is high.

Keywords: parent, anxiety, newborn, transient tachypnea of newborn 
Y enidoğanın geçici takipnesi (YGT), yenidoğanlarda solunum sıkıntısı oluşturan başlıca nedenlerdendir. Fetal akciğer sıvısının yeterli oranda ve hızda atılamamasından kaynaklandığı düşünülür $(1,2)$. Bu sendromla doğan bebeklerin doğumundan hemen sonra; inleme, göğüs retraksiyonu, siyanoz ve takipne görülür. Genellikle düşük miktarda oksijen desteğine intiyaç duyulur. Belirtiler bir kaç saat ya da bir hafta boyunca sürebilir. Bu süreçte yenidoğanın yakından takip edilmesi ve uygun tedavinin yapılması gerekir (3).

YGT tanısı ile tedavi alan bebeklerin ebeveynlerinde genelde anksiyete görülür. Anksiyete (kaygı); nedeni bilinmeyen, içten gelen, belirsiz, korku, kaygı, sıkıntı, kötü bir şey olacakmış endişesi ile yaşanan bir bunaltı duygusudur. Yaşamı tehdit eden ya da tehdit şeklinde algılanan bir çeşit alarm duygusudur. İçten ya da dıştan gelen tehlikeler ya da tehlike beklentilerine karşı yaşanan bir tepkidir. Ortamdaki değişmelerden her birey etkilenir. Ancak bazı bireyler bu değişmelerden daha çok etkilenir. Gerekli görülürse psikolojik tedavi ile desteklenirler (4-8).

Hastanede veya yoğun bakımda (YB) olmak çocuk kadar ebeveynlerin de üzerinde olumsuz etkiler oluşturarak yoğun stres ve anksiyete yaşamalarına neden olur. YB deneyimi sırasında bebekten ayrı kalınması nedeniyle ebeveyn rolünde eksiklikler olması, bebeğin geleceğinin ve bebeği ile eve gitmesinin belirsizliği, bebeğe evde nasıl bakılacağını bilememenin yarattığı korku, hastalığın ne olduğunun ve sorunların ne doğuracağının bilinmemesi strese neden olan durumlardır $(9,10)$.

Ebeveynlerin çocukları hastanede yatarken ortaya çıkabilecek yeni durumlarla ilgili olarak ve aile dinamiklerindeki değişiklikler açısından yardıma gereksinimi vardır. YB'de çocuğu olan ebeveynler temel olarak, doğru ve güvenilir şekilde bilgilendirmeye, çocuklarının durumlarını kendilerine açıklayacak birine ve personel dışında birinden duygusal, ruhsal ve fiziksel destek görmeye gereksinim duyarlar. Ayrıca, çocuklarının olası en iyi bakımı aldığına güven duymaları ve çocuklarına aktif bir şekilde ebeveynlik yapma fırsatları yaratılması aileyi destekleme açısından önemlidir (10-12).

Bebekleri için kaygılanan anne ve baba bu süreçte oldukça sıkıntılı zamanlar geçirirler. Hayal ettikleri gibi bebeklerini sağlıklı bir şekilde kucaklarına alabilme endişesi taşırlar. Belirsizlikler ebeveynleri psikolojik olarak zorlar. Bu durumda anne de ve baba da anksiyete oluşur, oldukça etkilenirler. Bu araştırmanın amacı, YGT ile hastaneye yatırılan bebeklerin ebeveynlerindeki kaygı düzeyi ve ilişkili faktörlerin incelenmesi amacıyla gerçekleştirildi.

\section{Yöntem}

Araştırmanın yapıldığı yer

Zonguldak il merkezinde bulunan T.C. Sağlık Bakanlığı'na bağıı bir kamu hastanesinin Yenidoğan Yoğun Bakım Ünitesi (YYBÜ)'nde gerçekleştirildi.

\section{Araştırmanın tipi}

Araştırma tanımlayıcı ve analitik tipte bir çalışmadır.

\section{Araştırmanın evreni ve örneklemi}

Araştırmanın evrenini Sağlık Bakanlığına bağlı kamu hastanesinin yenidoğan yoğun bakım ünitesinde bebekleri yatan ebeveynler oluşturdu. Çalışmanın örneklemi G*Power programında yapılan güç analizi ile belirlendi. Örneklem büyüklüğü G Power analizi ile $\% 90$ güç esas alınarak hesaplandı. Yapılan güç analizi sonucunda; \%90 güç, 0,05 Tip-1 hata ile tespit edilen gruplardaki örneklem sayısı minimum 150'şer kişi olması gerektiği hesaplanmış olup, araştırma süresince ebeveynlerin çalışmadan ayrılma olasılığı gözönüne alınarak, istatistiksel gücün olumsuz etkilenmemesi amacıyla örnek sayısının en az 200 olmasına karar verildi.

\section{Ebeveynler için araştırma kapsamına alınma kriterleri:} Ebeveynin araştırmaya katılmaya istekli olması, araştırmaya katılmasının yazılı ve sözlü onayının olması, en az ilkokul mezunu olan ebeveynler alındı.

\section{Bebekler için araştırma kapsamına alınma kriterleri:} "Yenidoğanın geçici takipnesi" tanısı alarak hastaneye yatırılan, 37-42 haftalık olan ve konjenital anomalisi olmayan bebekler alındı.

\section{Veri toplama araçları}

Araştırmada veri toplama aracı olarak Ebeveyn ve Bebek Bilgi Formu, Spielberger Durumluk ve Sürekli Kaygı Envanteri kullanıldı.

Ebeveyn Bilgi Formu: Araştırmacılar tarafından literatür bilgileri doğrultusunda hazırlanan form ebeveynlerin yaş, cinsiyet, medeni durum, eğitim durumu gibi özelliklerini sorgulayan 16 adet sorudan oluştu (13-15).

Bebek Bilgi Formu: Araştırmacılar tarafından literatür bilgileri doğrultusunda hazırlanan form bebeklerin doğum haftası, cinsiyeti, doğum kilosu, doğum şekli, hastanede 
yattığı gün sayısı, solunum durumunun nasıl olduğu gibi özelliklerini sorgulayan sekiz adet sorudan oluştu $(16,17)$.

\section{Spielberger Durumluk ve Sürekli Kaygı Envanteri} (STAI): Spielberger, Gorsuch ve Lushene tarafından 1970 yılında geliştirilen envanter, durumluk ve sürekli kaygıyı ölçen 20'şer ifadeli 2 alt ölçekten oluşmaktadır. Durumluk Kaygı Alt Ölçeği (STAI-S), bireyin belli bir anda ve belli koşullarda; Sürekli Kaygı Alt Ölçeği (STAI-T) ise, genellikle nasıl hissettiğini betimlemesini gerektirir. Envanter 4 noktalı ölçekler aracılığıyla cevaplanır. Durumluk Kaygı Alt Ölçeği maddelerinde ifade edilen duygu ve davranışlar, bu tür yaşantıların şiddet derecesine göre '(1) Hiç, (2) Biraz, (3) Çok ve (4) Tamamıyla' seçeneklerinden biri seçilerek belirtilir. Sürekli Kaygı Alt Ölçeği maddelerinde ifade edilen duygu ve davranışlar ise, sıklık derecelerine göre; '(1) Hemen Hiçbir Zaman, (2) Bazen, (3) Çok Zaman ve (4) Hemen Her Zaman' şeklinde işaretlenir. Her bir alt ölçekten alınan yüksek puanlar, kaygı düzeyinin yüksek olduğunu göstermektedir. Envanterin orijinal formunun test-tekrar test ve Kuder-Richardson güvenilirlik oranları sırasıyla, Durumluk Kaygı Alt Ölçeği için .16 - .54 ve .83 - .92; Sürekli Kaygı Alt Ölçeği için ise, .73 - .86 ve .86 - .92 şeklinde bulunmuştur (18). STAI'nin Türkçe'ye uyarlama, geçerlilik ve güvenilirlik çalışması 1983 yılında Öner ve Le Compte tarafından yapılmıştır. Bu çalışmada envanterin Kuder-Richardson güvenilirliği, Sürekli Kaygı Alt Ölçeği için .83 - .87; Durumluk Kaygı Alt Ölçeği için ise .94 - .96 arasında bulunmuştur. Madde güvenilirliği korelasyonlarının, Sürekli Kaygı Alt Ölçeği için .34 - .72; Durumluk Kaygı Alt Ölçeği için ise .42.85 arasında bulunması, Türkçeleştirilmiş maddelerin güvenilir olduğuna işaret etmektedir. Envanterin test tekrar test güvenilirlik oranları ise, Sürekli Kaygı Alt Ölçeği için .71 ile .86; Durumluk Kaygı Alt Ölçeği için .26 - .68 arasında olup yeterli kabul edilmiştir. Envanterin mevcut örneklem için Cronbach's a iç tutarlııı oranları, Durumluk Kaygı Alt Ölçeği ve Sürekli Kaygı Alt Ölçeği için sırasıyla .96 ve .90 olarak bulunmuştur.

\section{Verilerin toplanması}

Araştırmanın verileri çalışmanın yapıldığı kurumdan ve Bülent Ecevit Üniversitesi Klinik Araştırmalar Etik Kurulundan gerekli izinler alındıktan sonra Şubat- Ağustos 2017 tarihleri arasında örneklem kapsamına alınan ebeveynlerin bilgilendirilmiş onayları alınmıştır. Ebeveyn ve Bebek Tanıtım Bilgi Formu, Spielberger Durumluk ve Sürekli Kaygı Envanteri yüz yüze görüşme yöntemi ile araştırmacı tarafından ebeveynlere iletilmiş ve formların doldurulması sağlanmıştır.
Verilerin değerlendirilmesi

Çalışmada elde edilen bulgular değerlendirilirken istatistiksel analizler için NCSS (Number Cruncher Statistical System) 2007 (Kaysville, Utah, USA) programı kullanıldı. Çalışma verileri değerlendirilirken tanımlayıcı istatistiksel metotların (Ortalama, Standart Sapma, Medyan, Frekans, Oran, Minimum, Maksimum) yanı sıra niceliksel verilerin karşılaştırılmasında normal dağılım gösteren değişkenlerin iki grup karşılaştırmalarında Student $t$ test, üç ve üzeri grup karşılaştırmalarında Oneway Anova test kullanıldı. İstatistiksel anlamlılık düzeyi $p<0.05$ olarak kabul edildi.

\section{Bulgular}

\section{Ebeveyn bilgilerine ilişkin bulgular}

Araştırmaya katılan ebeveynlerin \%50'sini anneler ve \%50'sini babalar oluşturmuştur. Ebeveynlerin \%30,5'i $(n=61)$ lise mezunu, $\% 29,5^{\prime} i(n=59)$ ortaokul mezunu, $\% 20,5$ 'i ( $n=41$ ) ilkokul mezunu, \%17,'si ( $n=34)$ üniversite mezunu, $\% 1,5^{\prime} i(n=3)$ okuryazar ve $\% 1^{\prime} i(n=2)$ ise okuryazar olmadığını ifade etmiştir (Tablo 1).

Tablo 1. Ebeveyn demografik özelliklerine ilişkin dağılımlar

\begin{tabular}{|c|c|c|c|}
\hline & & $n$ & $\%$ \\
\hline \multirow[t]{2}{*}{ Ebeveyn } & Anne & 100 & 50.0 \\
\hline & Baba & 100 & 50.0 \\
\hline \multirow[t]{5}{*}{ Yaş } & $15-19$ yaş & 3 & 1.5 \\
\hline & $20-24$ yaş & 25 & 12.5 \\
\hline & $25-29$ yaş & 60 & 30.0 \\
\hline & $30-34$ yaş & 67 & 33.5 \\
\hline & $\geq 35$ yaş & 45 & 22.5 \\
\hline \multirow[t]{6}{*}{ Eğitim durumu } & Okuryazar değil & 2 & 1.0 \\
\hline & Okuryazar & 3 & 1.5 \\
\hline & İlkokul mezunu & 41 & 20.5 \\
\hline & Ortaokul mezunu & 59 & 29.5 \\
\hline & Lise mezunu & 61 & 30.5 \\
\hline & Üniversite mezunu & 34 & 17.0 \\
\hline \multirow[t]{2}{*}{ Herhangi bir işte çalışma durumu } & Evet & 103 & 51.5 \\
\hline & Hayır & 97 & 48.5 \\
\hline \multirow[t]{4}{*}{ Meslek } & Memur & 17 & 8.5 \\
\hline & İşçi & 63 & 31.5 \\
\hline & Serbest meslek & 31 & 15.5 \\
\hline & Diğer & 89 & 44.5 \\
\hline \multirow[t]{2}{*}{ Kronik hastalık durumu } & Evet & 12 & 6.0 \\
\hline & Hayır & 188 & 94.0 \\
\hline \multirow[t]{2}{*}{ Sigara/ Alkol kullanımı } & Evet & 59 & 29.5 \\
\hline & Hayır & 141 & 70.5 \\
\hline \multirow[t]{2}{*}{ Bebeğin istenen gebelik ile doğması } & Evet & 163 & 81.5 \\
\hline & Hayır & 37 & 18.5 \\
\hline \multirow[t]{5}{*}{ Ailedeki çocuk sayı } & 1 & 85 & 42.5 \\
\hline & 2 & 64 & 32.0 \\
\hline & 3 & 41 & 20.5 \\
\hline & 4 & 6 & 3.0 \\
\hline & 5 & 4 & 2.0 \\
\hline
\end{tabular}


Bebeklerin yoğun bakım ünitesine yatırılma süreleri incelendiğinde; \%63'ünün ( $n=126)$ doğumdan hemen sonra, \%16,5'inin ( $n=33$ ) ilk 1 saat içinde, \%6'sının ( $n=12)$ 1-24 saat içinde ve \%14,5'inin ( $n=29) 1$ gün veya daha sonrasında yoğun bakıma alındığı saptanmıştır (Tablo 2).

Tablo 2. Doğum sonrası özelliklerin dağlımları

\begin{tabular}{|c|c|c|c|}
\hline & & $n$ & $\%$ \\
\hline \multirow{2}{*}{$\begin{array}{l}\text { Doğumdan hemen sonra bebeği } \\
\text { görme }\end{array}$} & Evet & 136 & 68.0 \\
\hline & Hayır & 64 & 32.0 \\
\hline \multirow{4}{*}{$\begin{array}{l}\text { Doğumdan sonra bebeği görme } \\
\text { zamanı }\end{array}$} & 1-30 dk. sonra & 113 & 56.5 \\
\hline & 30-60 dk. sonra & 29 & 14.5 \\
\hline & 1-24 saat sonra & 48 & 24.0 \\
\hline & Diğer & 10 & 5.0 \\
\hline \multirow{5}{*}{$\begin{array}{l}\text { Bebeği ilk gördüğünde } \\
\text { hissedilen duygu }\end{array}$} & Mutluluk & 124 & 62.0 \\
\hline & Karmaşık duygular & 39 & 19.5 \\
\hline & Üzüntü & 6 & 3.0 \\
\hline & Heyecan, şaşkınlık & 29 & 14.5 \\
\hline & Anksiyete & 2 & 1.0 \\
\hline \multirow{4}{*}{$\begin{array}{l}\text { Bebeğin yoğun bakım ünitesine } \\
\text { yatırılma zamanı }\end{array}$} & Hemen & 126 & 63.0 \\
\hline & İlk 1 saat içinde & 33 & 16.5 \\
\hline & 1-24 saat içinde & 12 & 6.0 \\
\hline & $\geq 1$ gün sonrasında & 29 & 14.5 \\
\hline \multirow{2}{*}{$\begin{array}{l}\text { Bebek hastanede iken evde } \\
\text { olmak isteme }\end{array}$} & Evet & 11 & 5.5 \\
\hline & Hayır & 189 & 94.5 \\
\hline \multirow{2}{*}{$\begin{array}{l}\text { Bebeğin hastalığı hakkında } \\
\text { yeterince bilgilendirilme }\end{array}$} & Evet & 145 & 72.5 \\
\hline & Hayır & 55 & 27.5 \\
\hline \multirow[t]{5}{*}{ Bebeği ziyaret sıklığı } & Her gün & 180 & 90.0 \\
\hline & Haftada 1 kez & 12 & 6.0 \\
\hline & Haftada 2 kez & 1 & 0.5 \\
\hline & $\geq$ Haftada 3 kez & 5 & 2.5 \\
\hline & Hiç & 2 & 1.0 \\
\hline \multirow{3}{*}{$\begin{array}{l}\text { Bebek ziyareti esnasında } \\
\text { hissedilen duygu }\end{array}$} & Mutluluk & 130 & 65.0 \\
\hline & Üzüntü & 32 & 16.0 \\
\hline & Anksiyete & 38 & 19.0 \\
\hline
\end{tabular}

\section{Bebek bilgilerine ilişkin bulgular}

Araştırmaya katılan ebeveynlerin \%38'i $(n=76)$ normal doğum, \%58, $5^{\prime} i(n=117)$ sezaryen doğum ve $\% 3,5^{\prime} i(n=7)$ normal doğuma yardımcı aletlerle doğumun gerçekleştiğini ifade etmişlerdir. Bebeklerin \% $\% 5^{\prime i}(n=10)$ solunum makinesine bağlı olarak, \%70,5'i ( $n=141)$ kuvöz içinde oksijen alarak ve $\% 24,5^{\prime} \mathrm{i}(\mathrm{n}=49)$ ise yardımsız soluyabilmişlerdir (Tablo 3).
Tablo 3. Bebek tanımlayıcı özelliklerine ilişkin dağılımlar

\begin{tabular}{|c|c|c|c|}
\hline & & $N$ & $\%$ \\
\hline \multirow[t]{2}{*}{ Cinsiyet } & Erkek & 110 & 55.0 \\
\hline & $\mathrm{KIz}$ & 90 & 45.0 \\
\hline \multirow[t]{4}{*}{ Doğum haftası } & 37-38 hafta & 23 & 11.5 \\
\hline & 38-39 hafta & 65 & 32.5 \\
\hline & 39-40 hafta & 86 & 43.0 \\
\hline & 40-42 hafta & 26 & 13.0 \\
\hline \multirow[t]{3}{*}{ Doğum kilosu } & $\leq 2000 \mathrm{gr}$ & 4 & 2.0 \\
\hline & $2000-4000 \mathrm{gr}$ & 190 & 95.0 \\
\hline & $\geq 4000 \mathrm{gr}$ & 6 & 3.0 \\
\hline \multirow[t]{3}{*}{ Doğum şekli } & Normal & 76 & 38.0 \\
\hline & Sezaryen & 117 & 58.5 \\
\hline & $\begin{array}{l}\text { Normal doğuma } \\
\text { yardımcı aletlerle }\end{array}$ & 7 & 3.5 \\
\hline \multirow[t]{3}{*}{ Hastanede yattığı gün sayısı } & 1-24 saat & 6 & 3.0 \\
\hline & 1-7 gün & 187 & 93.5 \\
\hline & $\geq 1$ hafta & 7 & 3.5 \\
\hline \multirow[t]{3}{*}{ Solunum durumu } & $\begin{array}{l}\text { Solunum makinesine } \\
\text { bağlı }\end{array}$ & 10 & 5.0 \\
\hline & $\begin{array}{l}\text { Kuvöz içinde oksijen } \\
\text { alıyor }\end{array}$ & 141 & 70.5 \\
\hline & Yardımsız soluyabiliyor & 49 & 24.5 \\
\hline \multirow[t]{2}{*}{ Solunum dışı problem durumu } & Evet & 33 & 16.5 \\
\hline & Hayır & 167 & 83.5 \\
\hline \multirow{2}{*}{$\begin{array}{l}\text { Daha önce yeni doğanın geçici } \\
\text { takipnesi tanısı ile hastaneye } \\
\text { yatan çocuk durumu }\end{array}$} & Evet & 15 & 7.5 \\
\hline & Hayır & 185 & 92.5 \\
\hline
\end{tabular}

Spielberger durumluk ve sürekli kaygı envanteri değerlendirmesine ilişkin bulgular

Ebeveynlerin durumluk kaygı puanları 20 ile 71 arasın-

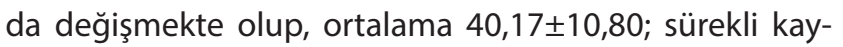
gı puanları 35 ile 66 arasında saptanmış olup, ortalama

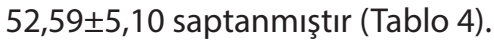

\section{Tablo 4. Durumluk ve sürekli kaygı puanlarının dağıııları}

\begin{tabular}{lcc} 
& Durumluk kaygı puanı & Sürekli kaygı puanı \\
\hline Min-Mak (Medyan) & $20-71(40)$ & $35-66(53)$ \\
Ort \pm Ss & $40.17 \pm 10.80$ & $52.59 \pm 5.10$
\end{tabular}

Anneler ve babaların durumluk kaygı puanları arasında istatistiksel olarak anlamlı farklılık saptanmazken ( $p>0,05$ ); babaların sürekli kaygı puanları annelerden anlamlı düzeyde yüksek bulunmuştur ( $p=0,009 ; p<0,01)$.

Eğitim durumuna göre durumluk kaygı puanları arasında istatistiksel olarak anlamlı farklılık saptanmazken $(p>0,05)$; 
sürekli kaygı puanları arasında istatistiksel olarak anlamlı farklılık saptanmıştır ( $p=0,003 ; p<0,01)$. Anlamlı farklıı̆ı̆ın sebebini öğrenmek için yapılan ikili karşılaştırmalar sonu$\mathrm{cu}$; lise mezunu puanlarının, ilkokul $(p=0,004)$ ve ortaokul $(p=0,037)$ mezunu puanlarından anlamlı düzeyde yüksek bulunmuştur $(p<0,05)$ (Tablo 5$)$.

Tablo 5. Ebeveyn demografik özelliklerine göre durumluk ve sürekli kaygı puanlarının değerlendirmesi

\begin{tabular}{|c|c|c|c|c|}
\hline & & & $\begin{array}{l}\text { Durumluk } \\
\text { kaygı puanı }\end{array}$ & $\begin{array}{c}\text { Sürekli } \\
\text { kaygı puanı }\end{array}$ \\
\hline & & $n$ & Ort $\pm S s$ & Ort $\pm S s$ \\
\hline \multirow[t]{3}{*}{ Ebeveyn } & Anne & 100 & $41.40 \pm 10.80$ & $51.64 \pm 5.60$ \\
\hline & Baba & 100 & $38.93 \pm 10.80$ & $53.53 \pm 4.50$ \\
\hline & ${ }^{a p}$ & & 0.107 & $0.009^{* \star}$ \\
\hline \multirow[t]{5}{*}{ Yaş } & $15-24$ yaş & 28 & $37.71 \pm 9.60$ & $53.50 \pm 4.60$ \\
\hline & $25-29$ yaş & 60 & $40.33 \pm 10.40$ & $51.95 \pm 5.60$ \\
\hline & 30-34 yaş & 67 & $40.21 \pm 11.80$ & $52.94 \pm 5.10$ \\
\hline & $\geq 35$ yaş & 45 & $41.40 \pm 10.80$ & $52.33 \pm 4.80$ \\
\hline & ${ }^{\mathrm{b} p}$ & & 0.569 & 0.524 \\
\hline \multirow[t]{5}{*}{ Eğitim durumu } & $\begin{array}{l}\text { İlkokul mezunu } \\
\text { ve altı }\end{array}$ & 46 & $39.65 \pm 10.00$ & $51.22 \pm 4.80$ \\
\hline & $\begin{array}{l}\text { Ortaokul } \\
\text { mezunu }\end{array}$ & 59 & $41.80 \pm 11.20$ & $52.07 \pm 4.90$ \\
\hline & Lise mezunu & 61 & $38.25 \pm 11.00$ & $54.52 \pm 5.00$ \\
\hline & $\begin{array}{l}\text { Üniversite } \\
\text { mezunu }\end{array}$ & 34 & $41.47 \pm 10.80$ & $51.85 \pm 5.40$ \\
\hline & ${ }^{\mathrm{b}} \mathrm{p}$ & & 0.280 & $0.003^{* *}$ \\
\hline \multirow{3}{*}{$\begin{array}{l}\text { Herhangi bir işte } \\
\text { çalışma durumu }\end{array}$} & Evet & 103 & $39.86 \pm 11.60$ & $52.75 \pm 4.80$ \\
\hline & Hayır & 97 & $40.48 \pm 10.00$ & $52.41 \pm 5.40$ \\
\hline & ap & & 0.687 & 0.644 \\
\hline \multirow[t]{5}{*}{ Meslek } & Memur & 17 & $44.47 \pm 11.10$ & $50.94 \pm 6.00$ \\
\hline & İşçi & 63 & $38.11 \pm 10.70$ & $53.27 \pm 450$ \\
\hline & $\begin{array}{l}\text { Serbest } \\
\text { meslek }\end{array}$ & 31 & $40.10 \pm 11.20$ & $52.84 \pm 5.50$ \\
\hline & Diğer & 89 & $40.82 \pm 10.60$ & $52.33 \pm 5.20$ \\
\hline & ${ }^{b} p$ & & 0.153 & 0.364 \\
\hline \multirow{3}{*}{$\begin{array}{l}\text { Kronik hastalık } \\
\text { durumu }\end{array}$} & Evet & 12 & $37.3 \pm 9.70$ & $53.50 \pm 6.40$ \\
\hline & Hayır & 188 & $40.31 \pm 10.90$ & $52.53 \pm 5.00$ \\
\hline & ap & & 0.443 & 0.524 \\
\hline \multirow{3}{*}{$\begin{array}{l}\text { Sigara/ Alkol } \\
\text { kullanımı }\end{array}$} & Evet & 59 & $39.00 \pm 8.80$ & $53.34 \pm 4.60$ \\
\hline & Hayır & 141 & $40.65 \pm 11.60$ & $52.27 \pm 5.30$ \\
\hline & ap & & 0.327 & 0.178 \\
\hline \multirow{3}{*}{$\begin{array}{l}\text { Bebeğin istenen } \\
\text { gebelik ile } \\
\text { doğması }\end{array}$} & Evet & 163 & $40.10 \pm 10.60$ & $52.36 \pm 5.30$ \\
\hline & Hayır & 37 & $40.46 \pm 11.80$ & $53.57 \pm 4.30$ \\
\hline & ${ }^{a} p$ & & 0.855 & 0.196 \\
\hline \multirow{4}{*}{$\begin{array}{l}\text { Ailedeki çocuk } \\
\text { sayı }\end{array}$} & 1 çocuk & 85 & $41.13 \pm 10.70$ & $52.56 \pm 4.80$ \\
\hline & 2 çocuk & 64 & $40.03 \pm 11.80$ & $52.77 \pm 5.50$ \\
\hline & $\geq 3$ çocuk & 51 & $38.73 \pm 9.80$ & $52.39 \pm 5.10$ \\
\hline & ${ }^{\mathrm{b} p} \mathrm{p}$ & & 0.455 & 0.927 \\
\hline
\end{tabular}

aStudent $t$ Test, ${ }^{b}$ Oneway ANOVA Test
Bebeğin yoğun bakıma yatırılma zamanına göre sürekli kaygı puanları arasında istatistiksel olarak anlamlı farklılık saptanmazken ( $p>0,05)$; durumluk kaygı puanları arasında istatistiksel olarak anlamlı farklılık saptanmıştır ( $p=0,004$; $p<0,01)$. Anlamlı farklılığın hangi gruptan kaynaklandığını saptamak için yapılan ikili karşılaştırmalar sonucu; 1 gün ve daha uzun süre sonrasında yoğun bakıma yatanların puanları, hemen yatan $(p=0,003)$ ve ilk 1 saat içinde yatanlardan $(p=0,023)$ anlamlı düzeyde yüksek bulunmuştur $(p<0,05)$. Diğer ikili karşılaştırmalarda istatistiksel olarak anlamlı farklılık saptanmamıştır ( $p>0,05)$.

Bebek hastalığı hakkında yeterince bilgilendirilme durumuna göre sürekli kaygı puanları arasında istatistiksel olarak anlamlı farklılık saptanmazken ( $p>0,05)$; bilgilendirilen ebeveynlerin durumluk kaygı puanı bilgilendirilmeyenlerden anlamlı düzeyde düşük bulunmuştur $(p=0001$; $p<0,01)$. Bebeği ziyaret esnasında hissedilen duyguya göre sürekli kaygı puanları arasında istatistiksel olarak anlamlı farklılık saptanmazken ( $p>0,05)$; durumluk kaygı puanları arasında istatistiksel olarak anlamlı farklılık saptanmıştır ( $p=0,001 ; p<0,01)$. Anlamlı farklılığın hangi gruptan kaynaklandığını saptamak için yapılan ikili karşılaştırmalar sonucu; üzüntü yaşayanların puanları, mutlu olanlardan $(p=0,032)$ ve anksiyete yaşayanlardan $(p=0,001)$ anlamlı düzeyde yüksek bulunmuştur ( $p<0,05)$ (Tablo 6).

Doğum şekline göre durumluk ve sürekli kaygı puanları istatistiksel olarak anlamlı farklılık göstermezken ( $p>0,05)$; sezaryen doğum olanların durumluk ve sürekli kaygı puanlarının, normal doğum olanlardan düşük olması dikkat çekmiştir. Solunum durumuna göre sürekli kaygı puanları arasında istatistiksel olarak anlamlı farklılık saptanmazken ( $p>0,05)$; durumluk kaygı puanları arasında istatistiksel olarak anlamlı farklılık saptanmıștır ( $p=0,001 ; p<0,01)$. Anlamlı farklılığın hangi gruptan kaynaklandığını saptamak için yapılan ikili karşılaştırmalar sonucu; bebeği yardımsız soluyanların puanları, solunum makinesine bağlı olanlardan $(p=0,026)$ ve kuvöz içinde oksijen alanlardan $(p=0,002)$ anlamlı düzeyde düşük bulunmuştur $(p<0,05)$ (Tablo 7).

\section{Tartışma}

YGT tanısı konmuş bebekler için zaman ve ebeveynle etili iletişim çok önemlidir. Çalışma sonucuna göre YGT'li bebeklerin çoğu (\%63) hemen tespit edilip, yatışı gerçekleştirilir. YGT bulguları hemen ya da bir iki saat içinde ortaya çıkmaktadır. Bu nedenle YGT'li bebeklerin hızlı tespit edildiği düşünülmektedir (19). Bazen bebeğin YYBÜ'ye alınması ani gelişebilir. Bu süreçte sağlık personelleri 
Tablo 6. Doğum sonrası özelliklere göre durumluk ve sürekli kaygı puanlarının değerlendirmesi

\begin{tabular}{|c|c|c|c|c|}
\hline & & & $\begin{array}{l}\text { Durumluk } \\
\text { kaygı puanı }\end{array}$ & $\begin{array}{c}\text { Sürekli } \\
\text { kaygı puanı }\end{array}$ \\
\hline & & $n$ & Ort $\pm S s$ & Ort $\pm S s$ \\
\hline \multirow{3}{*}{$\begin{array}{l}\text { Doğumdan hemen } \\
\text { sonra bebeği görme }\end{array}$} & Evet & 136 & $39.68 \pm 11.70$ & $52.61 \pm 5.50$ \\
\hline & Hayır & 64 & $41.19 \pm 8.60$ & $52.53 \pm 4.30$ \\
\hline & ap & & 0.309 & 0.912 \\
\hline \multirow{5}{*}{$\begin{array}{l}\text { Doğumdan sonra } \\
\text { bebeği görme } \\
\text { zamanı }\end{array}$} & $\begin{array}{c}1-30 \mathrm{dk} \\
\text { sonra }\end{array}$ & 113 & $39.35 \pm 11.20$ & $52.66 \pm 5.40$ \\
\hline & $\begin{array}{l}30-60 \mathrm{dk} \\
\text { sonra }\end{array}$ & 29 & $42.41 \pm 11.70$ & $52.97 \pm 5.20$ \\
\hline & $\begin{array}{l}\text { 1-24 saat } \\
\text { sonra }\end{array}$ & 48 & $40.71 \pm 9.40$ & $51.79 \pm 4.50$ \\
\hline & Diğer & 10 & $40.20 \pm 11.00$ & $54.40 \pm 4.70$ \\
\hline & ${ }^{\mathrm{b} p}$ & & 0.575 & 0.459 \\
\hline \multirow{5}{*}{$\begin{array}{l}\text { Bebeği ilk } \\
\text { gördüğünde } \\
\text { hissedilen duygu }\end{array}$} & Mutluluk & 124 & $39.43 \pm 10.30$ & $52.66 \pm 5.20$ \\
\hline & $\begin{array}{l}\text { Karmaşık } \\
\text { duygular }\end{array}$ & 39 & $41.69 \pm 11.80$ & $52.62 \pm 5.00$ \\
\hline & $\begin{array}{l}\text { Heyecan, } \\
\text { şaşkınlık }\end{array}$ & 29 & $39.38 \pm 11.50$ & $51.90 \pm 5.30$ \\
\hline & Diğer & 8 & $47.00 \pm 10.20$ & $53.75 \pm 2.50$ \\
\hline & ${ }^{\mathrm{b} p}$ & & 0.197 & 0.811 \\
\hline \multirow{5}{*}{$\begin{array}{l}\text { Bebeğin yoğun } \\
\text { bakım ünitesine } \\
\text { yatırıma zamanı }\end{array}$} & Hemen & 126 & $38.85 \pm 10.50$ & $52.32 \pm 4.90$ \\
\hline & $\begin{array}{l}\text { İlk } 1 \text { saat } \\
\text { içinde }\end{array}$ & 33 & $39.09 \pm 11.30$ & $53.85 \pm 5.10$ \\
\hline & $\begin{array}{l}\text { 1-24 saat } \\
\text { içinde }\end{array}$ & 12 & $40.83 \pm 10.20$ & $51.83 \pm 4.80$ \\
\hline & $\begin{array}{c}\geq 1 \text { gün } \\
\text { sonrasında }\end{array}$ & 29 & $46.83 \pm 10.20$ & $52.62 \pm 6.10$ \\
\hline & ${ }^{\mathrm{b} p} \mathrm{p}$ & & $0.004^{\star *}$ & 0.456 \\
\hline \multirow{3}{*}{$\begin{array}{l}\text { Bebek hastanede } \\
\text { iken evde olmak } \\
\text { isteme }\end{array}$} & Evet & 11 & $44.09 \pm 12.90$ & $55 \pm 4.4$ \\
\hline & Hayır & 189 & $39.94 \pm 10.70$ & $52.44 \pm 5.1$ \\
\hline & ap & & 0.217 & 0.107 \\
\hline \multirow{3}{*}{$\begin{array}{l}\text { Bebek hastalığı } \\
\text { hakkında yeterince } \\
\text { bilgilendirilme }\end{array}$} & Evet & 145 & $38.46 \pm 10.60$ & $52.66 \pm 5.20$ \\
\hline & Hayır & 55 & $44.65 \pm 10.30$ & $52.40 \pm 5.00$ \\
\hline & ${ }^{a} p$ & & $0.001^{\star *}$ & 0.753 \\
\hline \multirow[t]{3}{*}{ Bebeği ziyaret sıklığı } & Her gün & 180 & $39.94 \pm 11.10$ & $52.54 \pm 5.20$ \\
\hline & Diğer & 20 & $42.20 \pm 7.80$ & $52.95 \pm 4.30$ \\
\hline & ap & & 0.377 & 0.737 \\
\hline \multirow{4}{*}{$\begin{array}{l}\text { Bebek ziyareti } \\
\text { esnasında } \\
\text { hissedilen duygu }\end{array}$} & Mutluluk & 130 & $40.32 \pm 11.30$ & $52.51 \pm 5.20$ \\
\hline & Üzüntü & 32 & $44.69 \pm 7.80$ & $52.81 \pm 4.70$ \\
\hline & Anksiyete & 38 & $35.84 \pm 9.80$ & $52.66 \pm 5.30$ \\
\hline & ${ }^{b} p$ & & $0.001^{* *}$ & 0.951 \\
\hline
\end{tabular}

${ }^{a}$ Student $t$ Test, ${ }^{b}$ Oneway ANOVA Test
Tablo 7. Bebek tanımlayıcı özelliklerine göre durumluk ve sürekli kayg puanlarının değerlendirmesi

\begin{tabular}{lccc} 
& $n$ & $\begin{array}{c}\text { Durumluk } \\
\text { kaygı puanı }\end{array}$ & $\begin{array}{c}\text { Sürekli } \\
\text { kaygı puanı }\end{array}$ \\
\hline Cinsiyet & Ort $\pm S s$ & Ort $\pm S s$ \\
Erkek & 110 & $40.63 \pm 11.40$ & $53.06 \pm 4.80$ \\
Kız & 90 & $39.60 \pm 10.10$ & $52.00 \pm 5.40$ \\
& ${ }^{a p}$ & 0.506 & 0.143 \\
\hline Doğum haftası & & & \\
$37-38$ hafta & 23 & $42.43 \pm 10.60$ & $51.22 \pm 5.00$ \\
$38-39$ hafta & 65 & $40.42 \pm 11.10$ & $52.71 \pm 4.20$ \\
$39-40$ hafta & 86 & $38.33 \pm 10.60$ & $53.23 \pm 5.50$ \\
$40-42$ hafta & 26 & $43.62 \pm 10.50$ & $51.35 \pm 5.70$ \\
& ${ }^{\circ p}$ & 0.103 & 0.204
\end{tabular}

\section{Doğum kilosu}

$2000-4000$ gr $\quad 190 \quad 39.99 \pm 10.90 \quad 52.56 \pm 5.20$

Diğer $\quad 10 \quad 43.40 \pm 10.30 \quad 53.00 \pm 3.20$

${ }^{\text {ap }} \quad 0.334 \quad 0.793$

\section{Doğum şekli}

$\begin{array}{llll}\text { Normal } & 83 & 41.84 \pm 11.20 & 53.33 \pm 4.80\end{array}$

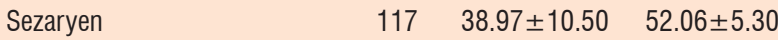

$\begin{array}{lll}{ }^{\text {ap }} & 0.065 & 0.084\end{array}$

\section{Solunum durumu}

Solunum makinesine bağı $\quad 10 \quad 45.00 \pm 11.10 \quad 52.80 \pm 3.70$

Kuvöz içinde oksijen alıyor $\quad 141 \quad 41.45 \pm 10.50 \quad 52.55 \pm 5.10$

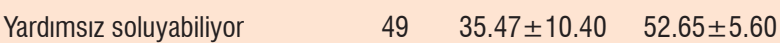

bp $\quad 0.001^{* *} \quad 0.983$

\section{Solunum dışı problem durumu}

$\begin{array}{llll}\text { Evet } & 33 & 40.03 \pm 11.30 & 53.70 \pm 5.30\end{array}$

Hayır $\quad 167 \quad 40.19 \pm 10.80 \quad 52.37 \pm 5.10$

$\begin{array}{lll}\text { ap } & 0.938 & 0.172\end{array}$

Daha önce yeni doğanın geçici takipnesi tanısı ile hastaneye yatan çocuk durumu

\begin{tabular}{lccc} 
Evet & 15 & $39.00 \pm 9.20$ & $54.53 \pm 3.50$ \\
Hayır & 185 & $40.26 \pm 11.00$ & $52.43 \pm 5.20$ \\
& ${ }^{\text {ap }}$ & 0.666 & 0.125 \\
\hline
\end{tabular}

aStudent $\mathrm{t}$ Test, ${ }^{\mathrm{b} O n e w a y ~ A N O V A}$ Test, ${ }^{* *} \mathrm{p}<0.01$ 
ebeveynlere bebekleri ile ilgili verilmesi gereken bilgileri ilk etapta veremeyebilirler. Ancak ziyaretleri sırasında ebeveynlere bebeğin olumlu yönlerinin gösterilmesi ve durumu hakkında bilgi verilmelidir. Çünkü YYBÜ ebeveynler için bilinmeyen bir ortamdır ve bu durum ebeveynin stres yaşamasına neden olur. Ayrıca bebeklerinden ayrımış olmaları, beklentilerinin karşılanmaması ebeveynin karmaşık duygulara bürünmesine sebep olarak onlarda huzursuzluk oluşturur (20).

Çalışmamızda YGT'li bebek annelerinin çoğunun $(\% 58,5)$ sezaryen ile doğum yaptığı görülmüştür. Sezaryen ile doğum YGT için bir risk faktörüdür. Yapılan çalışmalarda sezaryen ile doğum sonrası doğan bebeklerde YGT oranı daha fazla görülmüştür $(19,21)$. Çırlak ve ark.'nın (11) yaptığı çalışmada da annelerin 113'ü sezaryen doğum yaparken 63'ü ise normal doğum yapmaktadır. TNSA 2013 verilerine bakıldığında sezaryen ile doğum oranı giderek artmaktadır. Örneğin 2008'de sezaryen oranı \%37 iken, 2013 verilerine göre ise \%48'dir $(22,23)$.

Çekin'in (24) araştırmasında da prematüre bebeklerin $\% 32,7$ 'si solunum cihazına bağlı olarak, \%22,8'i küvez içi oksijenle, \%44,6'sı da yardımsız soluyabilmektedir. Bu sonuçlara bakıldığında solunum cihazına bağlanma riskinin, prematüre bebeklerde daha yüksek olduğu söylenebilir.

Ebeveyn bilgilerinin "Spielberger Durumluk ve Sürekli Kaygı Envanteri"ne göre tartışılması

Bebeği YGT ile YYBÜ'ye yatan ebeveynlerin kaygı durumlarına bakıldığında; ebeveynlerin sürekli kaygı puanları durumluk kaygı puanlarından daha yüksek oranda tespit edilmiştir. Bunun sebebinin; ebeveynlerin bebekleri için bilinmeyen gelecek duygusu olduğu düşünülmüştür. Ebeveyn hayallerinde sağlıklı bir bebek düşünürken, bebeğin hasta olması; ebeveynde hayal kırıklığı oluşturmuştur. Bu durum ebeveynde; suçluluk, utanç, anksiyete ve şok oluşturarak ebeveynin yıpranmasına neden olmuştur $(9,25)$.

Çalışır ve ark. (26), YYBÜ'de bebeği yatan ebeveynlerin kaygı düzeylerini konu edinen çalışmalarında annelerin kaygı düzeylerini babalarınkinden yüksek bulmuşlardır. Ancak bizim çalışmamıza katılan annelerin ve babaların kaygı durumları karşılaştııılığında; durumluk kaygı oranlarında anlamlı bir farklılık yokken ( $p>0,05)$, babaların sürekli kaygı puanları annelerin puanlarından daha yüksek bulunmuştur $(p=0,009 ; p<0,01)$. Annelerin sadece bebeklerinin o anki durumuna odaklandığı görülürken babaların hem yaşanan duruma hem de gelecek ile ilgili kaygılarının olduğu görülmüştür. Nedeninin annelerin duygusal yoğunluğunun baskın olmasına karşın, babaların bebekleri ile aralarındaki duygusal bağın henüz tam olarak kurulamamasından; babaların yaşanan bu duruma daha çok mantık çerçevesinden baktığı görülmüştür.

Konukbay ve Arslan'ın (27) çalışmasına göre YYBÜ'den en çok korkup stres duyan anne grubunun ilkokul mezunu anne grubunun (\%44) olduğu görülmüştür. Yaptığımız araştırmada ise ebeveynlerin eğitim düzeyinin ile kaygı düzeyinin doğru orantılı olduğu görülmüştür. Durumluk kaygı puanlarında anlamlı farklılık yokken ( $p>0,05)$; sürekli kaygı puanlarında anlamlı farklılık tespit edilmiştir $(p=0,003 ; p<0,01)$. Bunun nedeni ise; lise mezunlarının puanları, ilkokul $(p=0,004)$ ve ortaokul $(p=0,037)$ mezunlarından anlamlı düzeyde yüksek bulunmasıdır $(p<0,05)$. Eğitim düzeyi arttıkça insanların kaygı düzeyi artmıştır. Eğitim düzeyi yüksek olan insan düşük olanlara göre daha çok araştırır ve süreci daha yakından takip eder. En iyi ve en kötü ihtimali de öğrenmeye çalışır. Eğitim düzeyi yüksek olan insanların farkındalığı daha fazladır. Bu nedenle eğitim düzeyi arttıkça kaygının artması olağan bir durumdur.

YGT ile yoğun bakıma yatırılan bebeklerin yatııılma zamanına göre sürekli kaygı puanları arasında anlamlı farklılık yokken ( $p>0,05)$; durumluk kaygı puanları arasında anlamlı farklılık saptanmıştır $(p=0,004 ; p<0,01)$. Anlamlı farklılığın sebebine bakıldığında şu bilgi tespit edilmiştir; 1 gün ve daha uzun süre sonrasında YYBÜ'ye yatanların puanları, hemen YYBÜ'ye yatanlardan $(p=0,003)$ ve ilk 1 saat içinde YYBÜ'ye yatanlardan $(p=0,023)$ anlamlı düzeyde yüksek bulunmuştur $(p<0,05)$. Bebekleri yanlarına verilen ebeveynler, bebeklerine kavuşurlar ve kısa süre içerisinde bağlanma gerçekleşir. Her şey yolundayken doğumdan 1 gün sonra bebeğin hasta olduğunu, o yüzden YYBÜ'ye yatırıması gerektiği anlatıldığında, ebeveyn şaşııır ve bu duruma anlam veremez. Ebeveyn bebeklerinin sağlıklı olduğunu düşünürken hasta olduğu gerçeğini kabullenmekte zorlanır. Bu nedenle doğumdan 1 gün sonra YYBÜ'ye yatırılan bebeklerin ebeveynleri "şok" durumunu daha yoğun yaşarlar. Hastalığın derecesi hafif bile olsa bebekleri YYBÜ'ye yatan ebeveynler için bu bir krizdir. Ebeveynler bu durumda şok, kaygı, korku, acizlik hissi, durumu kavrayamama, umutsuzluk ve suçluluk hissederler (28).

Ebeveynlerin bebeklerinin hastalığı hakkında, yeterince bilgilendirilme durumuna bakıldığında; sürekli kaygı puanları arasında anlamlı farklılık saptanmazken ( $p>0,05)$; bilgilendirilen ebeveynlerin durumluk kaygı puanı bilgilendirilmeyenlerden anlamlı düzeyde düşük bulunmuştur ( $p=0001$; $p<0,01)$. Hemşire, ebeveynin sorularını cevaplamalı, bebeği 
hakkında bilgi vermelidir. Ebeveynin YYBÜ'ye bebeğini ziyarete geldiğinde, onun bebeği ile konuşmasına ve bebeğine dokunmasına izin verilmelidir. Ebeveynin anlayabileceği dilde bebeğin durumu anlatılmalıdır. Ebeveyne verilen açıklayıcı bilgiler ebeveynin anksiyetesini azaltır (12). Turan (29) çalışmasında annelerin bebekleriyle ilgili bilgi edinmelerini ve araştırma yapmalarını desteklemiştir. Çalışmada annelerin bilgi edinmelerinin, bilinmezliğin getirdiği korku, stres ve anksiyeteyi azalttığı görülmüştür. Akşit ve Cimete (30), çalışmalarında ebeveynlerin duygularının paylaşılması, onların sorunlarının dinlenilmesi ve paylaşımda bulunulması onların anksiyetesinin, stresinin azalttığını belirtmişlerdir. Ebeveynlerin kendileriyle aynı durumu yaşayan insanlarla iletişime geçmelerinin onları rahatlattığı görülmüştür. Çıkan sonuçlar literatürle uyumludur.

Ebeveynlerin bebeklerini ziyaret sırasında hissettikleri duyguya göre; sürekli kaygı puanları arasında anlamlı farklılık yokken ( $p>0,05)$; durumluk kaygı puanları arasında anlamlı farklılık bulunmuştur ( $p=0,001 ; p<0,01)$. Anlamlı farklıığın sebebi şudur; üzüntü yaşayanların puanları, mutlu olanlardan $(p=0,032)$ ve anksiyete yaşayanlardan $(p=0,001)$ anlamlı düzeyde yüksek bulunmuştur $(p<0,05)$. Bunun nedenin; bebeklerinde çeşitli tıbbi cihazların, araç ve gereçlerin takılı olması; her bir cihazdan çıkan değişik ses ve görüntüler, tanı tedavinin bilinmemesi, bebekte ileriye yönelik herhangi bir fiziksel ya da zihinsel hasarın kalma korkusu, bebeğin uzuvlarında damar yolu ya da kan alma işlemlerinden kalma morlukların olması, bebeğin ağlaması, sağlık personellerinin ebeveyne, bebekleri ile ilgili güven vermemesi, ekonomik zorluklar ve ebeveynlik görevini yapamamaktan kaynaklı oluşan "suçluluk" duygusu olabileceği düşülmüştür $(30,31)$.

\section{Bebek bilgilerinin "Durumluk Ve Sürekli Kaygı Ölçeği"ne göre} tartışılması

Doğum şekline göre bakıldığında; sezaryen doğum olanların durumluk ve sürekli kaygı puanlarının, normal doğum olanlardan düşük olarak bulunmuştur. Bunun sebebinin, normal doğumda yaşanan ağrılar, sancılar ve korkulardan oluştuğu görülmüştür. Fakat sezaryende anestezi ile doğum gerçekleştiğinden anne doğum sırasında acı hissetmez. Ayrıca sezaryende doktor doğum için uygun zamanı planlar ve genellikle o plan doğrultusunda doğum ilerler. Fakat normal doğumda ağrı, sancı beklenir. Dolayısıyla normal doğum aniden geliştiği için yine kaygıya neden olur. Dönmez ve ark. (32), yaptıkları çalışmada sezaryen ve normal doğum yapanların kaygı düzeylerini benzer bulmuşlardır. Fakat her iki doğum şeklinde de antepartum dönemdeki kaygı düzeyleri postpartum dönem kaygı düzeylerinden daha yüksek olduğu görülmüştür. Olieman ve ark. (33) ise araştırmalarında sezaryen doğum talep eden kadınların antepartum dönemdeki kaygı düzeylerinin normal doğumu tercih eden kadınlardan daha yüksek olduğunu bulmuşlardır.

Bebeklerin solunum durumuna göre ebeveynde oluşan sürekli kaygı puanları arasında anlamlı farklılık yokken ( $p>0,05$ ); durumluk kaygı puanları arasında anlamlı farklılık saptanmıştır $(p=0,001 ; p<0,01)$. Anlamlı farklılığın sebebine bakıldığında; bebeği yardımsız soluyanların puanlarının, solunum makinesine bağlı olanlardan $(p=0,026)$ ve kuvöz içinde oksijen alanlardan $(p=0,002)$ anlamlı düzeyde düşük bulunmuştur $(p<0,05)$. Bebeklerini, solunum cihazına bağlı olarak ya da oksijen ile desteklendiğini gören ebeveynler doğal olarak ani kaygı yaşayabilirler. Ebeveynlerin, sağlık personeli ile iletişim sonrası ya da bebeklerinde iyileşme gördüklerinde ise bu kaygı azalır. Yardımsız soluyan bebeklerin ebeveynlerinin, destekle soluyan bebeklerin ebeveynlerinden daha kaygılı olması normaldir. Çekin (24) çalışmasında, destekle soluyan bebeklerin ebeveynlerinin stres nedeninin taburcu olamama korkusu olduğunu ifade etmiştir.

\section{Sonuç ve öneriler}

Gebelerin normal doğumdan kaynaklanan kaygılarını düşürüp sezaryene olan ilgilerinin azaltılması için gebe eğitim ekibi (ebe, hemşire, kadın hastalıkları doktoru, çocuk doktoru) oluşturulmalıdır. Eğitim ekibinin normal doğumu özendirici ve teşvik edici broşür, eğitim kitapçıkları ve afiş oluşturarak gebeleri doğum yöntemleri hakkında bilgilendirmelidir. Ekibin güncel bilgilere sahip olup sürekli yayınları takip etmesi gerekir.

Ebeveynlerin sürekli kaygıları durumluk kaygılarından, babaların sürekli kaygıları annelerinkinden daha yüksek bulunmuştur. Ebeveyni rahatsız eden bu kaygının minimize edilebilmesi için sağlık profesyonellerinin bilgisi, becerisi, uzmanlığı ve etkili iletişimi ile güven ilişkisi kurarak ebeveynlere aile merkezli bakım vererek ve destek olarak ihtiyaç halinde psikolojik yardım almalarını sağlaması gerekir.

Bilgilendirilen ebeveynlerin durumluk kaygıları bilgilendirilmeyenlerden anlamlı düzeyde düşük bulunmuştur. Sağlık çalışanı, bebek ile ilgili bilgiyi zaman kaybetmeden aileyle paylaşmalıdır. Ebeveynlere empatiyle yaklaşarak, durumu onların anlayabileceği şekilde aktarmalıdır.

Bebeği yardımsız soluyan ebeveynlerin durumluk kaygıları, solunum makinesine bağlı olanlardan ve kuvöz içinde oksijen alanlardan anlamlı düzeyde düşük bulunmuştur. Ebeveyn için bebeğinin YYBÜ'ye yatacak kadar ciddi bir 
hastalığının olması stres oluşturan ve tedirgin edici bir durum iken bebeğinin solunum makinesine de bağlı olduğunu görmesi ve bebeğin prognozunun belirsizliği ebeveynde kaygının sürekli artmasına sebep olur. Ebeveynde oluşan kaygının azaltılması için; YGT tanısı ve solunum makinesinin kullanımının gerekliliği ebeveyne anlatılarak, bebeğin sağlık durumu hakkında bilgi verip bebeğinin bakımına katılması sağlanmalıdır.

\section{Kaynaklar}

1. Nada AM, Shafeek MM, El Maraghy MA, Nageeb AH, Salah El Din A. Ş, Awad MH. Antenatal corticosteroid administration before elective caesarean section at term to prevent neonatal respiratory morbidity: a randomized controlled trial. Eur J Obstet Gynecol Reprod Biol 2016;199:88-91. [CrossRef]

2. Ibrahim M, Omran A, AbdAllah NB, Ibrahim M, El-Sharkawy S. Lung ultrasound in early diagnosis of neonatal transient tachypnea and its differentiation from other causes of neonatal respiratory distress. J Neonatal Perinatal Med 2018;11:281-7. [CrossRef]

3. Jha K, Makker K. Transient tachypnea of the newborn. Stat pearls. Treasure Island (FL): Stat pearls publishing; 2019. pp.1-2. https:// www.ncbi.nlm.nih.gov/books/NBK430685/

4. Pelep-Popko O. Differentiation and test anxiety in adolescents. J Adolesc 2004;27:645-62. [CrossRef]

5. Naimi E, Babuei A, Moslemirad M, Rezaei K, Eilami O. The effect of spirituality intervention on the anxiety parents of hospitalized newborns in a neonatal department. J Relig Health 2019. [Epub ahead of print] [CrossRef]

6. Lufi D, Darliuk L. The interactive effect of test anxiety and learning disabilities among adolescents. Int J Educ Res 2005;43:236-49. [CrossRef]

7. Suadiye $Y$, Aydın A. Anksiyete bozukluğu olan ergenlerde bilişsel hatalar. J Clin Psy 2009;12:172-9.

8. Muris P, Field AP. Distorted cognition and pathological anxiety in children and adolescents. Cognition and Emotion 2008;22:395-421. [CrossRef]

9. Ward K. Perceived needs of parents of critically ill infants in a neonatal intensive care unit (NICU). Pediatr Nurs 2001;27:281-6.

10. Çavuşoğlu H. Hastaneye yatmanın çocuk ve aile üzerindeki etkileri. Yaşamı tehdit edici hastalığı olan çocuk. Çocuk sağlığı hemşireliği. Ankara: Sistem Ofset Basımevi; 2004. ss.91-106.

11. Çırlak A, Erdemir F. Yenidoğan yoğun bakım ünitelerinde yatan bebeklerin ebeveynlerinin rahatlık düzeyi. Anadolu Hemşirelik ve Sağlık Bilimleri Derg 2013;16:73-81. http://static.dergipark.org.tr/ article-download/imported/1025008001/1025007660.pdf?

12. Özyazıcıoğlu N, Güdücü Tüfekci F. Yenidoğan yoğun bakım ünitesinde bebekleri bakım alan ebeveynlerin kaygı ve umutsuzluk düzeylerini etkileyen faktorlerin incelenmesi. Atatürk Üniversitesi Hemşirelik Yüksekokulu Derg 2009;12:66-73. http://static.dergipark. org.tr/article-download/imported/1025000757/1025000742.pdf?

13. Özmen SK. Anne-baba eğitim programının çocuklardaki davranış sorunları ve anne-babaların depresyon düzeylerine etkisi. Eğitim Bilim 2013;38:98-113.

14. Erkan S, Toran M. Alt sosyo-ekonomik düzey annelerin çocuklarını kabul ve reddetme davranışlarının incelenmesi: Diyarbakır ili örneği. Hacettepe Üniversitesi Eğitim Fakültesi Derg 2004;27:91-7.

15. Durualp E, Bektaș G, Ergin D, Karaca E, Topçu E. Annelerin sigara kullanımı ile yenidoğanın doğum kilosu, boyu ve baș çevresi arasındaki ilișkinin incelenmesi. Ankara Üniversitesi Tıp Fakültesi Mecmuası 2011;64:119-26. [CrossRef]

16. Ofori BD, Le Tiec M, Bérard A. Risk factors associated with preterm birth according to gestational age at birth. Pharmacoepidemiol Drug Saf 2008;17:556-64. [CrossRef]
17. Hallman M. Delayed clearance of fetal lung liquid and sodium transport-genetic predisposition not evident yet. Acta Pediatrica 2005;94:258-60. [CrossRef]

18. Öner N, Le Compte A. Süreksiz durumluk/sürekli kaygı envanteri el kitabı, 2. Basım,. İstanbul: Boğaziçi Üniversitesi Yayınevi; 1998.

19. Ovalı F. Yenidoğanın Geçici Takipnesi. İçinde: Dağoğlu T, Ovalı F, editörler. Neonatoloji. İstanbul: Nobel Tıp Kitabevi; 2007. ss.347-9.

20. Fowlie PW, McHaffie H. Supporting parents in the neonatal unit. BMJ 2004;329:1336-8. [CrossRef]

21. Rijal P, Shrestha M. Analysis of Neonatal Respiratory Distress in Neonatal Intensive Care Unit at Nepal Medical College. J Nepal Health Res Counc 2018;16:131-5. [CrossRef]

22. Türkyılmaz AS, Çavlin A. Türkiye Nüfus ve Sağlık Araştırması, TNSA 2013, Nüfus Etütleri Enstitüsü, 2013. https://panel.kku.edu.tr/ Content/sosyoloji/Demografya/TNSA2013_sonuclar_sunum.pdf

23. Koç İ. Türkiye Nüfus ve Sağlık Araştırması, TNSA 2008, Nüfus Etütleri Enstitüsü, 2008. http://www.hips.hacettepe.edu.tr/tnsa2008/data/ tnsa_2008_sonuclar.pdf

24. Çekin B. Bir üniversite hastanesi yenidoğan yoğun bakım ünitesinde prematüre bebeği yatan ebeveynlerin stres düzeyi ve baş etme yontemleri (Yüksek Lisans Tezi), Denizli, 2014; ss.34-5.

25. Hagen IH, Svindseth MF, Nesset E, Orner R, Iversen VC. Validation of the neonatal satisfaction survey (NSS-8) in six Norwegian neonatal intensive care units: a quantitative cross-sectional study. BMC Health Serv Res 2018;18:222. [CrossRef]

26. Çalışır H, Şeker S, Güler F, Anaç Taşçıoğlu G, Türkmen M. Yenidoğan yoğun bakım ünitesinde bebeği yatan ebeveynlerin gereksinimleri ve kaygı düzeyleri. CÜ Hemşirelik Yüksekokulu Derg 2008;12:31-44.

27. Konukbay D, Arslan F. Yenidoğan yoğunbakım ünitesinde yatan yenidoğan ailelerinin yaşadıkları güçlüklerin belirlenmesi. Anadolu Hemşirelik ve Sağlık Bilimleri Derg 2011;14:16-22. http://static.dergipark.org.tr/article-download/ imported/1025002777/1025006051.pdf?

28. Erdeve Ö, Atasay B, Arsan S, Türmen T. yenidoğan yoğun bakım ünitesinde yatış deneyiminin aile ve prematüre bebek üzerine etkileri. Çocuk Sağlığı ve Hastalıkları Derg 2008;51:104-9. http:// www.cshd.org.tr/uploads/pdf_CSH_297.pdf

29. Turan T, Başbakkal Z, Özbek S. Effect of nursing interventions on stressors of parents of premature infants in neonatal intensive care unit. J Clin Nurs 2008;17:2856-66. [CrossRef]

30. Akşit S. Çocuğun yoğun bakım ünitesine kabulünde, annelere uygulanan hemşirelik bakımının annelerin anksiyete düzeyine etkisi, Yüksek Lisans Tezi (Danışman: Cimete G). İstanbul; 1998.

31. Blackburn S. Environmental impact of the NICU on developmental outcomes. J Pediatr Nurs 1998;13:279-89. [CrossRef]

32. Dönmez S, Yeniel ÖA, Kavlak O. Vajinal doğum ve sezaryen doğum yapan gebelerin durumluk kaygı düzeylerinin karşılaştırılması. Gümüşhane Üniversitesi Sağlık Bilimleri Derg 2014;3:908-16. http:// static.dergipark.org.tr/article-download/b6e9/f0f7/609f/impJA78YN37UG-0.pdf?

33. Olieman RM, Siemonsma F, Bartens MA, Garthus-Niegel S, Scheele $F$, Honig $A$. The effect of an elective cesarean section on maternal request on peripartum anxiety and depression in women with childbirth fear: a systematic review. BMC Pregnancy Childbirth 2017;17:195. [CrossRef] 